\title{
CYTOPROTECTIVE EFFECT OF ETHANOL FRACTION OF VERNONIA AMYGDALINA DEL. LEAVES AGAINST THE VERO CELLS
}

\author{
SAFRIANA ${ }^{1 *}$, ROSIDAH ${ }^{1}$, POPPY ANJELISA ZAITUN HASIBUAN ${ }^{1}$, DENNY SATRIA $^{2}$ \\ ${ }^{1}$ Department of Pharmacology, Faculty of Pharmacy, Universitas Sumatera Utara, Medan, Indonesia. ${ }^{2}$ Department of Pharmaceutical \\ Biology, Faculty of Pharmacy, Universitas Sumatera Utara, Medan, Indonesia. Email: safrianaabdullah@gmail.com
}

Received: 07 March 2018, Revised and Accepted:25 March 2018

\section{ABSTRACT}

Objectives: The objective of this study is to assess the cytoprotective effect of ethanol fraction (EtF) of Vernonia amygdalina Del. leaves EtF against Vero cells which induced by hydrogen peroxide $\left(\mathrm{H}_{2} \mathrm{O}_{2}\right)$.

Methods: Cytoprotective effects of EtF were analyzed by 3-(4,5-dimethylthiazolyl-2)2,5-dipheniltetrazolium bromide to Vero cells which induced by $0.8 \mathrm{mM} \mathrm{H}_{2} \mathrm{O}_{2}$, apoptosis was determined by flow cytometry, and reactive oxygen species (ROS) expression was analyzed by immunocytochemistry.

Results: EtF was showed the largest percentage viable cell $(78.75 \pm 2.51 \%)$ at $50 \mu \mathrm{g} / \mathrm{mL}$. In the analysis of apoptosis by flow cytometry was showed the percentage of viable cell count of $59.56 \%$ and EtF was decreased the expression of ROS.

Conclusion: EtF has cytoprotective activity toward Vero cells induced by $0.8 \mathrm{mM} \mathrm{H}_{2} \mathrm{O}_{2}$.

Keywords: Cytoprotective, Vernonia amygdalina Del., Ethanol Fraction, Hydrogen peroxide, Vero cells.

(C) 2018 The Authors. Published by Innovare Academic Sciences Pvt Ltd. This is an open access article under the CC BY license (http://creativecommons. org/licenses/by/4. 0/) DOI: http://dx.doi.org/10.22159/ajpcr.2018.v11s1.26610

\section{INTRODUCTION}

Cancer is a disease of abnormal cell growth and quick characterized by uncontrolled cell division and the ability to invade other tissues [1,2]. Physiologically, the system in individual cell growth is regulated by a system of balance, i.e., apoptosis and proliferation. In the event of excessive apoptosis, it will be deprived of the function of an organ system that can cause disease. Conversely, if there is excessive proliferation, it will form a mass of tumor (malignancy) that will lead to cancer $[3,4]$.

Free radicals are atoms or molecules that have an unpaired electron in their outer orbitals and can stand alone [5]. Free radicals are generally composed of two forms of reactive oxygen species (ROS) and reactive nitrogen species. Both of these species result in mitochondrial dysfunction, impaired protein production, and aggregation of proteins that cause modulation of the activation of apoptosis, necrosis, and cell autophagis [6].

Antioxidants serve to overcome or neutralize free radicals and prevent damage to the body of the onset of degenerative diseases [7]. Therefore, we need a body of important substances, antioxidants, and compounds that have cytoprotective activities that may help protect the body from free radical attack to reduce the negative impact of these compounds. Most sources of natural antioxidants are plants and generally flavonoid. The ability of flavonoids as antioxidants has been studied in recent years, in which flavonoids have the ability to change or reduce free radicals and also as an anti-free radical [8].

Indonesia is a potential biological diversity in the discovery of new compounds are efficacious as anticancer, one of which is Africa leave (Vernonia amygdalina Del.). Plants originating from Africa are one of the plants of the Asteraceae tribe, which is widely used as a traditional medicine from the genus Vernonia.

Cytoprotective testing was done using MTT reagent in living cells. This method can be used to measure the number of cells, cytotoxicity, cell proliferation, and activity [9]. Vero cells are not cancerous epithelial cells (normal) derived from African green monkey kidney organ. Vero cell tests conducted to study cell growth, cell differentiation, cytotoxicity, and cell transformation induced various chemical compounds [10]. Agents used as an inducer of free radicals in the cytoprotective test are hydrogen peroxide $\left(\mathrm{H}_{2} \mathrm{O}_{2}\right)$.

\section{MATERIALS AND METHODS}

Material

$N$-hexane, ethyl acetate, and ethanol were purchased from Merck (Darmstadt, Germany), DMSO (Sigma-Aldrich Chemie GmBH Germany), 3-(4,5-dimethylthiazol-2-yl)-2,5-diphenyl tetrazolium bromide (MTT) (Sigma Chemical, St. Louis, MO), $\mathrm{H}_{2} \mathrm{O}_{2}$ from Merck Darmstadt, Germany), M199 media and phosphate-buffered saline (PBS) 10\% v/v (Gibco, Grand Island, NY, USA).

\section{Plant material}

The samples used were Africa leaves ( $V$. amygdalina Del.) and were still fresh. Sampling was done purposively without comparing with the same plants from other regions. Samples were taken from Tangkul Street, Kelurahan Sidorejo Hilir, Districts of Medan Tembung, Medan, North Sumatera.

\section{Plant and preparation of fractions}

The leaves of $V$. amygdalina Del. were dried at $45^{\circ} \mathrm{C}$ and ground into powder. The dried leaves powder (500 g) was extracted with n-hexane by maceration method. After 3 days of maceration at room temperature, the supernatant was separated by decantation, and the marc was macerated twice, the marc of n-hexane extract was extracted with ethyl acetate by maceration. The same procedure was applied to ethanolic extract. Extract from each solvent was concentrated by a rotary evaporator (Heidolph VV-200), and the concentrated extract was dried by freeze-dryer (Edwards).

\section{Cell lines and culture conditions}

Vero cell lines (African green monkey kidney) were kindly provided by Parasitology Laboratory, Faculty of Medicine, Gadjah Mada University, Indonesia. The cell lines were cultured in M199 medium, supplemented with $10 \%(\mathrm{v} / \mathrm{v})$ FBS, $2 \%$ penicillin-streptomycin, and $0.5 \%$ fungizone in a $37^{\circ} \mathrm{C}$ incubator with $5 \% \mathrm{CO}_{2}$. 


\section{Cytoprotective assay}

MTT assays

Cytoprotective activity was determined by the MTT colorimetric assay. Vero cell lines were plated at $10^{4}$ cells/well in a 96-well plate. The culture cells were incubated in a humidified incubator at $37^{\circ} \mathrm{C}$ at atmosphere of $5 \% \mathrm{CO}_{2}$ and $95 \%$ air for $24 \mathrm{~h}$. After incubation for $24 \mathrm{~h}$ at $37^{\circ} \mathrm{C}$, the medium was discharged, and cells were treated by ethanol fraction (EtF) of $V$. amygdalina with different concentration and incubated for $24 \mathrm{~h}$. After that, cell was induced with $0.8 \mathrm{mM} \mathrm{H}_{2} \mathrm{O}_{2}$ for $3 \mathrm{~h}$. MTT $0.5 \mathrm{mg} / \mathrm{mL}$ solution was added to each well and further incubated for $4 \mathrm{~h}$ at $37^{\circ} \mathrm{C}$. Viable cells react with MTT to produce purple formazan crystals. After $4 \mathrm{~h}$, the stopper $10 \%$ SDS (Sigma Co. St. Louis) in $0.01 \mathrm{~N}$ $\mathrm{HCl}$ (Merck) was added to dissolve the formazan crystal. The cells were then incubated for $24 \mathrm{~h}$ in room temperature and protected from light. After incubation, the cells were shaken. Optical density was read with an ELISA reader at $\lambda 595 \mathrm{~nm}$. The experimental data were absorbance of each well and then converted to percentage of viable cells [11-13].

Percentage of viablecell $=\frac{B-C}{A-C} \times 100 \%$

Where A, B, and C are absorbance of control group, treatment group, and medium (vehicle), respectively.

\section{Apoptosis analysis}

Annexin $\mathrm{V}$ kit was added to sediment and suspended and incubated at $37^{\circ} \mathrm{C}$ for $30 \mathrm{~min}$. The samples were analyzed using FAC Scan flow cytometer

\section{Immunocytochemistry assays}

$5 \times 10^{4}$ cells/well (Vero cells) were planted into 24 well pads covered with a coverslip on the bottom, incubated for $24 \mathrm{~h}$. Induced with $0.8 \mathrm{mM} \mathrm{H}_{2} \mathrm{O}_{2}$ for $3 \mathrm{~h}$ and treated with EtF, incubated for $24 \mathrm{~h}$. After incubation, the cells were washed with PBS and then fixed with cold methanol at $4^{\circ} \mathrm{C}$ for $10 \mathrm{~min}$. After that, the cells were washed with PBS and blocked in hydrogen peroxide $\left(\mathrm{H}_{2} \mathrm{O}_{2}\right)$ blocking solution for $10 \mathrm{~min}$ at room temperature, incubated using primary antibody ROS for $1 \mathrm{~h}$ and washed 3 times with PBS, depleted secondary antibody, incubated 10 min, washed cells again with PBS and spilled with streptavidin horseradish peroxidase enzyme and incubated for $10 \mathrm{~min}$, then added 3.3'-diaminobenzidine and incubated for 5 min (until brown), washed again with PBS and aquadest then with Mayer-Hematoxylin and incubated for $5 \mathrm{~min}$. Washed the cells back using aquadest, then added $70 \%$ incubation ethanol for $2 \mathrm{~min}$, cleaned, drops the xylol solution, and drained. Then placed coverslip on the glass objects and dinted mounting media and covered with a glass cover, conducted by observation with a microscope equipped with Optilab and use Software Image Raster

\section{Statistical analysis}

All data were expressed as half maximal inhibitory concentration (IC $\left.{ }_{50}\right)$ that analyzed using probit in regression at SPSS 19; test was used for statistical analyses with $\mathrm{p}=0.05$ was considered significant.

\section{RESULTS AND DISCUSSION}

MTT Methods [3-(4,5-dimetiltiazol-2-yl)-2,5-diphenyl tetrazolium bromide] is a quantitative test. This test is based on measuring the intensity of the color (colorimetric) that occurs as a result of metabolism of a substrate by living cells into a colored product [8]. The reduction of yellow tetrazolium MTT is reduced by metabolically active cells, in part by the action of dehydrogenase enzymes, to generate reducing equivalents such as NADH and NADPH. The resulting intracellular purple formazan can be solubilized quantified by spectrophotometric means. The extract showed cytoprotective activities in a concentrationdependent manner (Fig. 1).

Based on Fig. 1 can be seen that $\mathrm{H}_{2} \mathrm{O}_{2}$ is a source of oxidant in this study, the concentration of $0.8 \mathrm{mM}$ is used to induce cell damage, at these concentrations decrease the number of living cells up to $5 \%$ compared with the control Vero cells without $\mathrm{H}_{2} \mathrm{O}_{2}$ treatment. In this study, the intracellular level of $\mathrm{H}_{2} \mathrm{O}_{2}$ in Vero cells is greatly increased, but after administration of EtF in Vero cells with various concentrations of $100 \mu \mathrm{g} /$ $\mathrm{mL}, 50 \mu \mathrm{g} / \mathrm{mL}, 25 \mu \mathrm{g} / \mathrm{mL}, 12.5 \mu \mathrm{g} / \mathrm{mL}$, and $6.25 \mu \mathrm{g} / \mathrm{mL}$ showed increased cell viability value compared to the value of a given cell viability Vero $\mathrm{H}_{2} \mathrm{O}_{2}$.

In this study, it can be seen that EtF has cytoprotective activity to treatment with the test sample EtF shows percent viability at a concentration of $100 \mu \mathrm{g} / \mathrm{mL}$ of $63.72 \pm 1.36 \%, 50 \mu \mathrm{g} / \mathrm{mL}$ of $78.75 \pm 2.51 \%, 25 \mu \mathrm{g} / \mathrm{mL}$ of $75.51 \pm 1.79 \%, 12.5 \mu \mathrm{g} / \mathrm{mL}$ of $71.61 \pm 0.93 \%$, and $6.25 \mu \mathrm{g} / \mathrm{mL}$ of $66.72 \pm 1.53 \%$. Therefore, the highest percentage of living cells can be seen at concentrations of $50 \mu \mathrm{g} / \mathrm{ml}$.

Vero cells treated with EtF concentration of $50 \mu \mathrm{g} / \mathrm{mL}$ showed a high viability value of $78.75 \pm 2.51 \%$ compared with the concentration of other series. This is related to a previous study by Hartati, 2015, that conducts research on cytotoxic activity against Vero cells with $\mathrm{IC}_{50}$ value of $79.561 \mu \mathrm{g} / \mathrm{mL}$. The concentration of the test solution is smaller than the $\mathrm{IC}_{50}$ value cytotoxic activity has a value greater cell protection, while the concentration of the test solution is greater than the $\mathrm{IC}_{50}$ value indicates a decrease in the number of living cells [14].

EtF has a cytoprotective activity because more secondary metabolites contained therein, such as the content of flavonoid compounds. Flavonoids are antioxidants that are beneficial in preventing cell damage from oxidative stress. The mechanism of action of flavonoids as antioxidants can be directly or indirectly. Flavonoids as antioxidants directly are by inhibiting the oxidation reaction through the mechanism of free-radical scavengers by donating an electron to the unpaired electron that can neutralize the toxic effects of free radicals. Flavonoids as antioxidants indirectly, namely, by increasing the gene expression of antioxidant through several mechanisms. One mechanism is an increase in antioxidant gene expression through activation of nuclear factor erythroid-related factor 2 (Nrf2) resulting in an increase in genes involved in the synthesis of endogenous antioxidant enzymes such as SOD (superoxide dismutase) [15].

Evaluation of apoptosis induction was performed using flow cytometry method with Annexin-V as shown in Fig. 2.

As shown in Fig. 2, the cells in the upper and lower right quadrants represent late apoptotic/necrotic and early apoptotic cells, respectively. The percentage of control, control $+\mathrm{H}_{2} \mathrm{O}_{2}$ and $\mathrm{EtF}$ in viable cell $80.56 \%, 10.32 \%$, and $59.56 \%$ in early apoptotic $9.42 \%, 10.93 \%$, and $16.66 \%$ in late apoptotic/early necrotic $2.97 \%, 45.72 \%$, and $7.94 \%$, and in late necrotic $7.04 \%, 33.03 \%$, and $15.85 \%$. In the apoptotic study, EtF increased the number of viable cells compared to control $+\mathrm{H}_{2} \mathrm{O}_{2}$ Vero cell lines. In the treatment showed that EtF had cytoprotective activity through apoptosis mechanism.

Analysis of ROS expression was performed using immunocytochemistry methods with specific antibody binding principles. In this analysis, secondary antibody added served as a liaison between primary antibodies with streptavidin-horseradish peroxidase enzymes. Streptavidin-horseradish peroxidase enzymes can be seen with the addition of 3,3'-diaminobenzidin as a chromogen solution which will

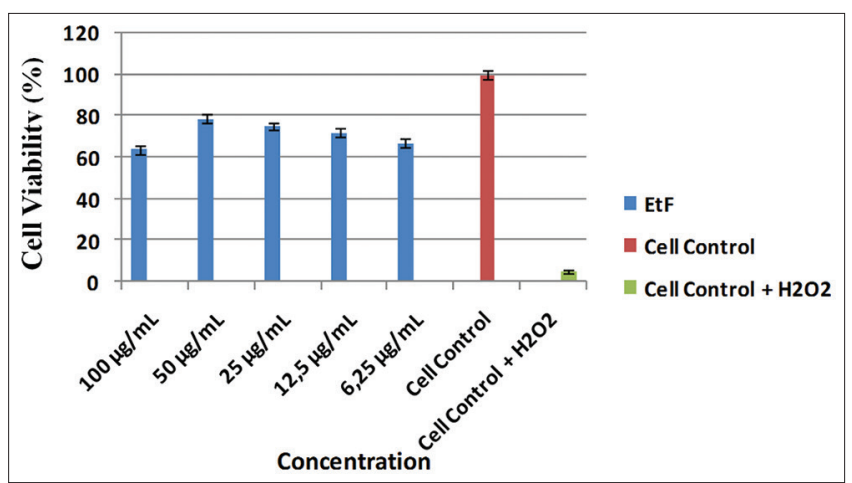

Fig. 1: Graph concentration test solution to the percent of cell viability 


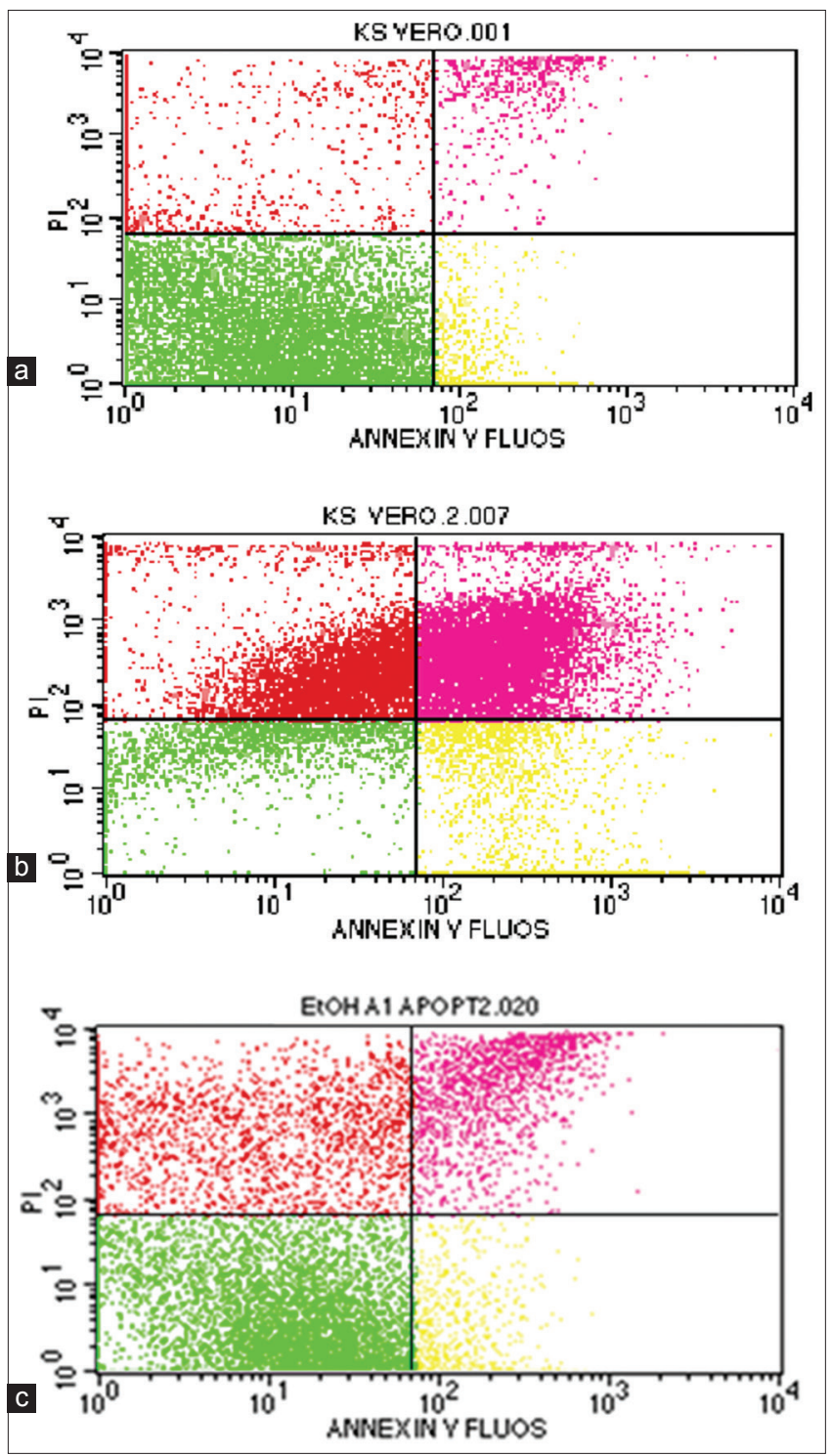

Fig. 2: Apoptosis analysis using flow cytometry. Vero cells were treated by ethanol fraction (EtF) for $24 \mathrm{~h}$ and stained using annexin-V. (a) control cells, (b) control cells+hydrogen peroxide, (c) $\mathrm{EtF} 50 \mu \mathrm{g} / \mathrm{mL}$

produce a brown color. This indicated the presence of ROS or positive results. ROS expression on Vero cell can be seen in Fig. 3.

Based on Fig. 3. a strongly positive brown that means positive expression on $\mathrm{H}_{2} \mathrm{O}_{2}$ induced cells, irregular cell shape and cell nuclei shrink as seen in Fig. $3 \mathrm{~b}$. The negative expression showed the blue color shown in Fig. 3a and c. $\mathrm{EtF}$ can decreased ROS expression as indicated by the reduced brown color of the cells compared to the dominant $\mathrm{H}_{2} \mathrm{O}_{2}+$ cell control. This shows that Etf has cytoprotective activity, so there are few cells that express ROS. An increased formation of ROS/free radicals leads to depletion of endogenous antioxidants. Flavonoids effectively act as anti-oxidants by two methods. First, they can increase the ability of endogenous anti-oxidants. Secondly, they can interfere with three different ROS/Free radical producing systems in the human body [16]. Many studies had revealed that flavonoid content in plants could be correlated to their antioxidant activities Plants including vegetables contained flavonoid compounds can act as antioxidant. Flavonoids may be the major contributors for the antioxidant activity [17].

\section{CONCLUSION}

EtF can improve the viability of Vero cells induced by $\mathrm{H}_{2} \mathrm{O}_{2}$. By variation of the concentration of $6.25-100 \mu \mathrm{g} / \mathrm{mL}$ showed increased cell viability
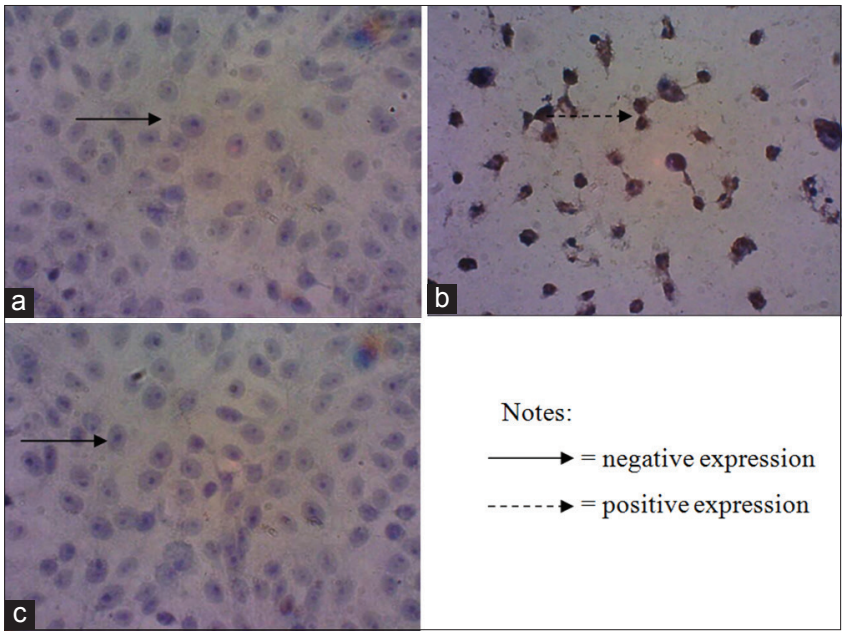

Notes:

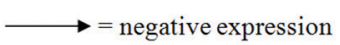

$-\cdots=$ positive expression

Fig. 3: Reactive oxygen species expression analysis using

immunocytochemistry. (a) control cells, (b) Control

cells+hydrogen peroxide, (c) Ethanol fraction $50 \mu \mathrm{g} / \mathrm{mL}$

value compared to the value of a given cell viability Vero $\mathrm{H}_{2} \mathrm{O}_{2}$. EtF the MTT test shows the percent viability, respectively, by $78.75 \pm 2.51 \%$ with a concentration $50 \mu \mathrm{g} / \mathrm{mL}$ EtF. EtF had cytoprotective activity through apoptosis mechanism and EtF can decreased ROS expression.

\section{REFERENCES}

1. Diandana R. Knowing the Details of Cancer. $3^{\text {rd }}$ ed. Yogyakarta: Katahati; 2009. p. 15, 22, 29-30.

2. Hawari D. Breast Cancer Psychoreligy Dimensions. Jakarta: FKUI Publisher; 2004. p. 12-5.

3. Sudiana IK. Molecular CancerPathobiology. Jakarta: Salemba; 2011. p. $1,29-52,71-5$.

4. Sharma RA. Cancer Chemoprevention: A Clinical Reality. J R Soc Med 2000;93:518-20.

5. Clarkson PM, Thompson HS. Antioxidants: What role do they play in physical activity and health. J Clin Nutr Biochem 2000;72:637-46.

6. Navarro YJ, Zavala FL, Anandhan A, Wang F, Skotak M, Chandra N, et al. Antioxidant Gene Therapy Against Neuronal Cell Death. J Pharmacol Ther 2014;142:206-30.

7. Kosasih EN, Tony S, Hendro H. The Role of Antioxidants on Elderly. Jakarta: National Center for The Geriatrics Problems; 2006. p. 67-78.

8. Giorgio PP. Flavonoids as antioxidants. J Nat Prod 2000;63:1035-42.

9. Montagnon BJ, Fanget B, Nicolas AJ. the large scale cultivation of vero cells in micro carrier culture for virus vaccine production. preliminary results for killed poliovirus vaccine. Dev Biol Standard 1981;47:55-64.

10. Goncalves EM, Ventura CA, Yano T, Macedo ML, Ganeri SC. Morphological and growth alterations in vero cells transformed by cysplatin. Cell Biol Int 2006;30:485-94.

11. Anggraeni R, Hadisahputra S, Silalahi J, Satria D. Combinational effects of ethylacetate extract of Zanthoxylum acanthopodium DC. With doxorubicin on T47D breast cancer cells. Int J Pharmtech Res 2014;6:2032-5.

12. Hasibuan PA, Rosidah. Combination effect of ethylacetate extract of Plectranthus amboinicus (Lour.) Spreng. with Doxorubicin againts Hela Cell Lines. Int J Pharm Chem Res 2016;8:357-60.

13. Satria D, Silalahi J, Haro G, Ilyas S, Hasibuan PA. Antioxidant and antiproliferative activities of an ethylacetate fraction of picria fel-terrae Lour. Herbs. Asian Pac J Cancer Prev 2017;18:399-403.

14. Hartati E. Cytotoxic Effects of African leaf of Ethanol Extract (Vernonia amygdalina Del.) on hela cells and vero cells. Essay Medan: Faculty of Pharmacy. North Sumatera University; 2015.

15. Sumardika IW, Jawi IM. Water extract of sweet potato leaf improved lipid profile and blood SOD content of rats with high cholesterol diet. Med Sci J 2012;43:67.15.

16. Durga M, Nathiya S, DevasenaT. Immunomodulatory and antioxidant actions of dietary flavonoids. Int $\mathrm{J}$ of Pharm and Pharmaceutical Sci 2014;6(2):50-56

17. Figueroa LA, Navarro LB, Vera MP, Petricevich VL. Antioxidant activity, total phenolic and flavonoid contents, and cytotoxicity evaluation of bougainvillea xbuttiana. Int J of Pharm and Pharmaceutical Sci 2014;6(5):497-502. 